\title{
Strategic alliances and product development in high technology new firms: The moderating effect of technological capabilities
}

\author{
Carolin Haeussler $^{\mathrm{a}, *}$, Holger Patzelt ${ }^{\mathrm{b}, 1}$, Shaker A. Zahra ${ }^{\mathrm{c}, 2}$ \\ a Institute for Innovation Research, Technology Management, and Entrepreneurship, Ludwig-Maximilians - Universität München, Kaulbachstr. 45, 80539 München, \\ Germany \\ b Technische Universität München, Chair of Entrepreneurship, Karlstr. 45, 80333 München, Germany \\ c University of Minnesota, Department of Strategic Management E' Organization, Suite 3-428, Carlson School of Management, 321 19th Ave. South, \\ Minneapolis MN 55455, United States
}

\section{A R T I C L E I N F O}

\section{Article history:}

Received 24 June 2009

Received in revised form 25 August 2010

Accepted 19 October 2010

Available online 23 November 2010

Field Editor: P. Phan

\section{JEL classification:}

M13

L24

L25

\section{Keywords:}

High technology new firms

Strategic alliances

Capabilities perspective

New product development

Biotechnology industry

\begin{abstract}
A B S T R A C T
High technology new firms have extensively used strategic alliances to gain access to knowledge, resources and capabilities. However, given their inexperience and limited resources, these firms are vulnerable to their more established partners' potential opportunism. This raises the question: How can new firms maximize the benefits of these alliances while reducing their risks? In this study, we address this question by drawing upon the capabilities perspective to propose that the impact of upstream, horizontal, and downstream alliances on product development depends on the degree of specialization of new firms' technological capabilities. Using a database of biotechnology firms, the results support this argument even when different types of strategic alliances are considered.
\end{abstract}

(c) 2010 Elsevier Inc. All rights reserved.

\section{Executive summary}

New product development (NPD) and market introduction are important for high technology new firms' (HTNFs') successful performance. Yet, developing, testing and commercializing new products can be costly and time consuming processes and their outcomes are uncertain. As a result, many HTNFs have employed strategic alliances to gain the knowledge necessary to develop or acquire the capabilities needed for NPD. Many of the alliances that HTNFs have formed have been with established industry incumbents who possess the NPD-related resources, skills and expertise.

However, the need to access, acquire and assemble capabilities quickly may lead some HTNFs to join alliances under unfavorable conditions that make alliances unstable and prone to failure. These alliances could increase the risk of expropriation of the firm's own knowledge, undermining the new firms' competitive position. Reducing potential expropriation through the

\footnotetext{
* Corresponding author. Tel.: +49892180 5833; fax: +49 8921806284.

E-mail addresses: haeussler@lmu.de (C. Haeussler), patzelt@tum.de (H. Patzelt), Zahra004@umn.edu (S.A. Zahra).

1 Tel.: +498928926748.

2 Tel.: +1612 626 6623; fax: +16126261316.
} 
careful selection of partners and the use of contracts can be costly and HTNFs may lack the experiences or resources to do so effectively. HTNFs also lack the experience to manage the complexity of a large alliance portfolio and may not have the time, skills or resources necessary to monitor their partners.

How can HTNFs use strategic alliances more productively and mitigate the risks of these alliances? We address this question invoking the capabilities perspective to propose that the specialization of HTNFs' internal technological capabilities can significantly mitigate potential alliance benefits and risks. Using a sample of 199 biotechnology firms from Germany and the UK, we advance that the degree of specialization of a new firm's technological capabilities serves as a key organizational contingency that influences the impact of strategic alliances on NPD. This focus departs from, and extends, the literature that highlights the role of the alliance experience and slack resources as potential contingencies. Our results show that new firms can gain significantly from joining alliances by carefully exploiting their own technological capabilities to mitigate the risks involved. Given that different alliances can lead to different capabilities, we separate vertical upstream from downstream alliances that are vertically vs. horizontally in order to assess the interdependencies between a new firm's technological capability specialization and different types of alliances for a firm's NPD. Appreciating these varying effects can help HTNFs avoid unsuccessful alliances that can depress their performance and threaten their survival. For managers and entrepreneurs, our results suggest that HTNFs need to consider technological capabilities when selecting alliance partners. In particular, the specialization of HTNFs' technological capabilities can significantly influence their ability to acquire or access capabilities from external sources and to protect themselves from opportunistic partner behavior. The level of specialization of these capabilities, however, appears to have different effects with different types of alliances.

Our results also underscore the importance of new firms' technological capabilities in gaining and capturing knowledge from alliances and then using this knowledge in NPD. These capabilities and the level of HTNFs' specialization provide an important basis to examine the benefits and risks associated with alliances of different types, an issue that deserves examination in future studies in different high technology sectors. It is important also to identify and investigate the mechanisms by which HTNFs use their technological capabilities to absorb knowledge from their alliance partners. We hope our findings encourage researchers to pursue these issues.

\section{Introduction}

Turning research discoveries into marketable products and taking them to the market is important for new firms operating in high technology industries such as biotechnology, software, medical technology, and semiconductors. High technology new firms (HTNFs) are small and medium-sized enterprises that are too young to have completed a full new product development (NPD) cycle. ${ }^{3}$ These HTNFs often compete in dynamic and fierce environments (D'Aveni, 1994) and need to develop and commercialize new products in order to exploit promising market opportunities, generate needed cash flows, and make a profit. Yet, developing, testing and commercializing new products can be costly and time consuming processes, and their financial outcomes uncertain. For example, NPD in the biopharmaceutical industry can generate several billion \$US in revenues when a new blockbuster drug is successfully introduced to the market. Conversely, it can lead to the loss of hundreds of millions of $\$ U S$ if the drug candidate fails during late development stages (DiMasi et al., 2003).

HTNFs are often unable to assemble the right mix of capabilities needed for NPD internally (Eisenhardt and Schoonhoven, 1996). Capabilities denote "the set of tangible and intangible assets that enable an organization to develop, make, and market goods" (Gomes-Casseres, 1996: 30). In HTNFs, "those organizational capabilities or competencies which give rise to competitive advantage are not "simple" assets, but compound asset structures which are built over time and are path dependent" (Deeds et al., 1999: 213). For example, HTNFs' capabilities include the skills of their research teams, R\&D management skills, and access to external information sources (Deeds et al., 1999). Since it often takes years to develop these capabilities many HTNFs have joined strategic alliances to develop the capabilities needed for NPD (Hagedoorn, 1993; Rothaermel and Deeds, 2004; Shan et al., 1994; George et al., 2002; Patzelt et al., 2008). A strategic alliance is a cooperative relationship between two or more firms to develop and commercialize a product (Deeds and Hill, 1996). Many of the alliances that HTNFs have formed have been with established industry incumbents who have strong NPD-related resources. HTNFs are desired partners for incumbents to ally with in order to adapt to new technology and fill their product pipelines (Rothaermel, 2001).

However, the need to access, acquire and assemble capabilities quickly may lead some HTNFs to join alliances under unfavorable conditions that make these alliances unstable and even prone to failure (Lerner and Merges, 1998; Lerner et al., 2003). Indeed, in industries where NPD is based on specialized and complex organizational knowledge - defined as the explicit (e.g., patents and publications) or tacit (e.g., research expertise and R\&D management experience) knowledge embedded in the people and processes of the HTNF (De Carolis and Deeds, 1999) - alliances can increase the risk of expropriation of the firm's own knowledge (Pisano, 1990; Teece, 1986), potentially undermining the competitive position of new ventures. However, curbing potential expropriation through careful partner selection and the use of contracts can be costly and HTNFs may lack the experiences or resources to do so effectively (Lerner and Merges, 1998). HTNFs also lack the experience to manage the

\footnotetext{
${ }^{3}$ For example, in the software industry NPD might be completed within one year or less and a two-year old software firm might not qualify as a HTNF. However, in the biopharmaceutical industry NPD takes on average 12 years (DiMasi et al., 2003) and a 10-year old biopharmaceutical firm might still be a HTNF. While some HTNFs may not possess the skills needed for NPD in-house to market the resulting product, they may have licensed in/bought and marketed a product from other firms.
} 
complexity of a large alliance portfolio and may not have the time, skills or resources to monitor their partners (Deeds and Hill, 1996). New firms are often short on the resources, staff and expertise needed to monitor their established partners and safeguard against their potential opportunism.

The earlier discussion raises a question: How can HTNFs use alliances more productively and mitigate the risks of strategic alliances? In this paper, we address this question by drawing on the capabilities perspective (Teece, 1986; Das and Teng, 2000) and the literature on absorptive capacity (Cohen and Levinthal, 1990; Zahra and George, 2002) to propose that the specialization of HTNFs' internal technological capabilities can significantly mitigate potential alliance benefits and risks. These capabilities denote a firm's "ability to produce a component according to the required specification and schedule" (Hoetker, 2005: 78). Such capabilities influence HTNFs' market success and define its competitive advantage (Kogut and Zander, 1992; Martin and Salomon, 2003).

We propose that HTNFs can creatively exploit their technological capabilities to mitigate the risks of alliances while gaining the knowledge required for NPD. Specifically, the degree of specialization of a new firm's technological capabilities serves as a key organizational contingency that influences the impact of strategic alliances on NPD. To develop this argument, we distinguish between types of alliances (e.g., Rothaermel and Deeds, 2006) to understand the differential effects of the specialization of a firm's own technological capabilities on the benefits it gains while mitigating the risks of alliances. Given that different alliances can give new firms different capabilities, we separate vertical upstream from downstream alliances that are completed vertically vs. horizontally (Baum et al., 2000; Higgins and Gulati, 2006). Making this distinction allows us to assess the interdependencies between a firm's technological capability specialization and the different types of alliances the firm enters to promote NPD. Appreciating these effects can help HTNFs avoid unsuccessful alliances that can lower their performance and threaten their survival (Alvarez and Barney, 2001).

To test our argument, we use a unique survey dataset on 199 biotechnology firms' alliance activities, their set of technological capabilities, and NPD. In doing so, we contribute to the literature in three key ways. First, we introduce the degree of specialization of an HTNF's technological capabilities as an organizational contingency that influences the potential impact of strategic alliances on firm performance, specifically NPD. Prior research on new firm alliances has focused on alliance experience (Hoang and Rothaermel, 2005; Rothaermel and Deeds, 2006) and slack resources (Lerner et al., 2003) to explain variance in the benefits high technology firms gain from alliances. Second, the bulk of the literature has emphasized the benefits associated with alliances, but with few exceptions (e.g., Baum et al., 2000) researchers have rarely analyzed the negative consequences of alliances for the firms involved (Gulati, 1998). In this study, we show that entering into a new alliance can depress NPD and this effect is contingent on the composition of the firm's internal technological capabilities. Consequently, HTNFs stand to gain from joining alliances by carefully exploiting their own technological capabilities to mitigate the risks involved. Third, many existing studies on HTNFs' alliances have failed to distinguish between the types of alliances (Rothaermel and Deeds, 2006). Our distinction among upstream, horizontal, and downstream alliances enables us to assess the differential effects of the level of specialization of internal technological capabilities on maximizing the upside potential and mitigating the risks of each type of alliance for the new firms' NPD.

In the next section, we develop our theory and hypotheses. We then describe our sample and summarize the analysis and results. After discussing key findings we recognize the study's limitations, identify promising avenues for future research, and present our conclusion.

\section{Theory and hypotheses}

The capabilities perspective suggests that organizations need to have an appropriate stock of resources and capabilities and use them effectively to gain a competitive advantage (Amit and Schoemaker, 1993; Teece et al., 1997). For many HTNFs, building these capabilities internally can be a demanding and uncertain task. Capability development is an extremely complex, uncertain, costly, and time consuming process (Teece et al., 1997; DiMasi et al., 2003). Recipes for successful capabilities are not known beforehand. Further, having appropriate capabilities (e.g., for NPD) does not guarantee financial success. For example, only one out of 5000 initial product candidates in the biopharmaceutical industry reaches the market (Evans and Varaiya, 2003). Yet, high technology industries are dynamic and fiercely competitive environments (D'Aveni, 1994), giving HTNFs little time to build the various capabilities necessary to innovate and successfully commercialize their innovations. The need for multiple and often complex capabilities as well as uncertainty surrounding the acceptance of new products have prompted HTNFs to join alliances with other firms to acquire the different capabilities (Pisano, 1990; Zahra, 1996; Ahuja, 2000; Patzelt et al., 2008).

Success in gaining knowledge from partners usually depends on the firm's absorptive capacity, defined as its ability to identify and acquire knowledge from partners as well as understand and apply this knowledge for its own use (Cohen and Levinthal, 1990; Zahra and George, 2002). The development of absorptive capacity is a cumulative, path-dependent process that requires significant and sustained investments (Nelson and Winter, 1982; Powell et al., 1996). Though studies suggest that R\&D expenditures can enhance absorptive capacity (Arora and Gambardella, 1994), we propose that the specialization of a firm's technological capabilities may also significantly enrich this capacity and, as a result, may determine the benefits HTNFs derive from alliances.

Technological capabilities are knowledge-based and build on HTNFs' experiences and prior learning (Leiblein and Miller, 2003; Mayer and Nickerson, 2005).These capabilities denote a firm's "ability to produce a component according to the required specification and schedule" (Hoetker, 2005: 78). In high technology sectors, this ability is usually evident in a firm's scientific knowledge and competencies (Leiblein and Miller, 2003; Mayer and Nickerson, 2005). Therefore, in this study of HTNFs, we refer 
to technological capabilities as the different scientific techniques available to the firm. For example, in the biotechnology industry, scientific techniques include DNA/RNA based techniques, proteins and molecules, cell tissue culture and engineering as well as subcell techniques, process techniques, bioinformatics, and nanobiotechnology (OECD, 2005).

Some HTNFs might have a broad set of technological capabilities (a variety of scientific techniques), but others might have, or specialize in, one or a few capabilities, building expertise in particular activities. Developing a broad set of capabilities is a time consuming and costly task that requires coordination in the use of these capabilities. Conversely, narrow specialization may force HTNFs to target only a small portion of their products' value chain, missing NPD opportunities. For instance, while the early steps of the biopharmaceutical value chain (the research phase) require expertise in DNA/RNA based techniques and proteins/molecules, later product development phases require knowledge in cell tissue cultures and bioinformatics to evaluate the data gained from preclinical and clinical testing of the drug candidate.

Alliances of different types (vertical upstream, horizontal downstream and vertical downstream) might influence HTNFs' NPD (captured by the number of products a firm develops over time, cf. Deeds et al., 1999), the benefits to be gained from each type depends on the specialization of these firms' technological capabilities - as indicated in Fig. 1.

\subsection{Technological capabilities and vertical upstream alliances}

Alliances between HTNFs and established companies could be developed up or downstream, either vertically or horizontally. Among the most common are vertical upstream alliances, which are cooperative relationships that HTNFs establish with organizations upstream of their value chain (George et al., 2001). In science-based industries, HTNFs' upstream activities typically require interacting with universities and public research institutions that conduct basic research (George et al., 2002).

Upstream alliances give HTNFs access to the valuable specialized, scientific, and technological knowledge needed to develop new products (Deeds and Hill, 1996; Oliver and Liebeskind, 1998; Rothaermel and Deeds, 2006). Obtaining specialized knowledge (Argyres and Liebeskind, 1998) and benefiting from knowledge spillovers (Owen-Smith and Powell, 2004) can improve HTNFs' NPD in terms of speed and meeting design criteria (Zucker et al., 2002). Accessing knowledge through upstream alliances can also lower NPD costs (Kogut, 1988), allowing firms to allocate their financial resources among more projects. These cost savings result from sharing information, expertise, and personnel (Lewis, 1990; Geisler et al., 1990; Geisler, 1995).

If partners' knowledge is related to the HTNF's own knowledge domain, new firms can exploit their more specialized technological capabilities in ways that maximize their ability to acquire knowledge from upstream alliance partners. As noted, technological capabilities are an integral part of new firms' absorptive capacity (Leonard-Barton, 1995; Cohen and Levinthal, 1990). This capacity "is largely a function of the firm's level of prior related knowledge” (Cohen and Levinthal, 1990: 128). Knowledge acquisition from alliance partners becomes easier when the knowledge bases of both organizations are similar (Lane and Lubatkin, 1998). However, developing high levels of absorptive capacity in the particular knowledge domain of a potential alliance partner is challenging as the HTNF has to focus its scarce resources on building specialized technological capabilities in that domain. The more specialized the new firm's technological capabilities in a given domain, the higher its potential absorptive capacity in that area. Therefore, if the partner's knowledge domain is related to that of the firm, HTNFs with more specialized technological capabilities are apt to benefit more from forming learning alliances with universities than with firms that have less specialized technological capabilities. Moreover, when the firm has more specialized technological capabilities and its scientists have expertise related to the scientific field of the university alliance partner, the HTNF can better comprehend the methods used and the results achieved by its alliance partner. Higher knowledge domain expertise will also make communication easier, possibly lowering the need for costly coordination.

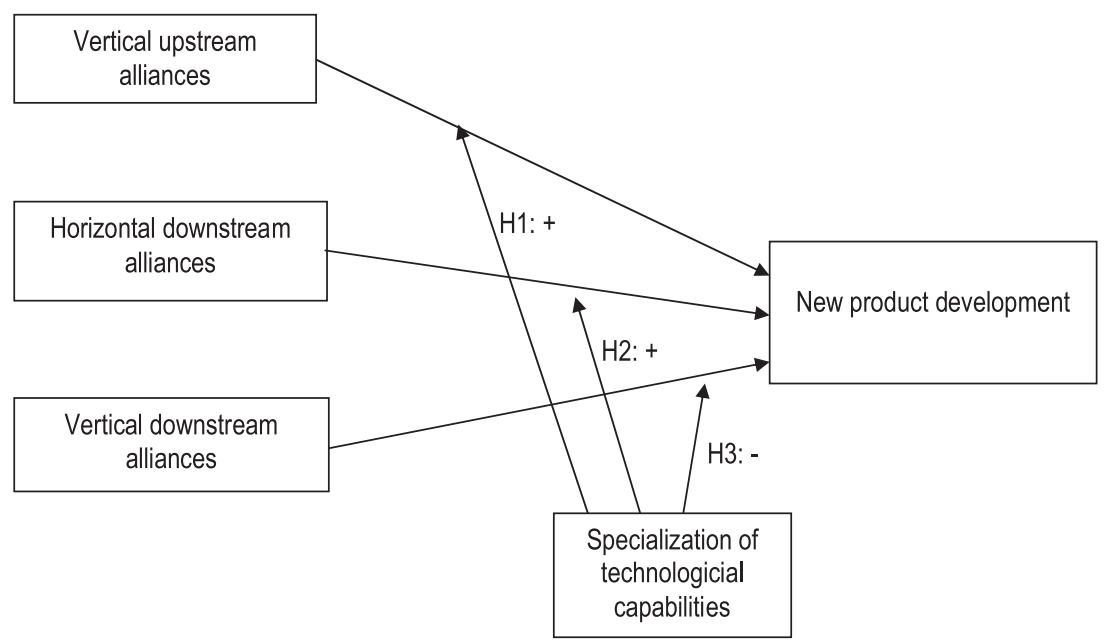

Fig. 1. Theoretical model. 
Even if the partner's knowledge domain is not related to the HTNF's main area of specialization at the time when the alliance is formed, more specialized technological capabilities could be beneficial. This is because vertical upstream alliances have risks of their own, and specialized capabilities can help mitigate these risks. The cultures of universities and business organizations are often incompatible with respect to secrecy and free exchange of knowledge (Bower, 1992). HTNF scientists usually emphasize knowledge related to NPD, keeping their knowledge secret and reduce its leakage to competitors. However, university scientists value generating publications (Dasgupta and David, 1994; Haeussler, 2010a). This discrepancy increases the need for coordination, possibly raising the overall costs of NPD. Increased costs may lower HTNFs' NPD because fewer resources are allocated directly to these activities.

In addition, having more specialized technological capabilities can mitigate HTNFs' risk in upstream alliances by reducing university scientists' incentive to develop knowledge that is publishable but irrelevant for the HTNF's purpose. Independent of their particular area of specialization, targeting their resources to build specialized technological capabilities allows HTNFs' scientists to work at the scientific frontier and perform cutting-edge research. Possession of in-depth knowledge can facilitate the effective exchange of information between HTNFs and universities (Hicks, 1995) even if the knowledge domains of both partners are unrelated. For example, when firm scientists know about recent scientific breakthroughs and the advancement of the field in general, this can help in the development of a common language with scientists of the university alliance partner and promote the exchange of ideas and develop mutual respect that fosters joint discovery. In their discussions with university scientists, deep scientific knowledge can also help firm scientists to judge the significance and future potential of new scientific developments and signal their competence. When the firm has deep scientific knowledge and understanding of the scientific process, university partners are less likely to behave opportunistically and pursue their own research interests that lead to publications rather than NPD because it is more difficult for them to do so without the partner recognizing it.

Further, over the course of the alliance university scientists may develop interest in the HTNF's technology in order to advance their own research and they might proceed to build up absorptive capacity in the HTNF's domain and expropriate knowledge from the HTNF. The more specialized and sophisticated the HTNF's technology, the better it is protected from its partner's opportunism. Thus, technological specialization can protect HTNFs, at least to some extent, against opportunistic behavior of upstream alliance partners irrespective of the HTNF's particular field of specialization. Therefore:

H1. The relationship between the number of vertical upstream alliances and product development is more positive when the internal technological capabilities of the high technology new firm are more specialized than when they are less specialized.

\subsection{Technological capabilities and horizontal alliances}

Horizontal alliances are established when HTNFs collaborate with other organizations at the same level of the value chain (Perry et al., 2004). These alliances enable HTNFs to reduce demand uncertainty, achieve and retain strategic flexibility, give customers a wider range of services, and explore growth opportunities (Burgers et al., 1993; Smith and Barclay, 1997). In turn, this allows HTNFs to develop new products by accessing their partners' knowledge in design, prototyping, testing, development, and commercialization (George et al., 2001).

Still, horizontal alliances entail a particularly high risk of failure because alliance partners at the same level of the value chain are often rivals (Gnyawali et al., 2006; Hamel et al., 1989). These alliances are not pure collaboration agreements; rather, they are mechanisms for "co-opetition" - a simultaneous cooperation and competition between partners (Brandenburger and Nalebuff, 1996). Though co-opetition can enhance firm performance (Lado et al., 1997), the competition between partners often becomes more prevalent than cooperation over the course of such an alliance (Khanna et al., 1998; Gnyawali and Madhavan, 2001). For example, Park and Russo (1996) have found that horizontal alliances in the electronics industry frequently fail because of rising competition among partners; this competition makes these alliances unstable (Mowery et al., 1996). The combination of the two fundamentally different logics of cooperation and competition (Bengtsson and Kock, 2000) makes risk sharing among partners or enforcing contracts to counter moral hazard problems challenging (Tapon, 1989; Deeds and Hill, 1998). The outcomes of the exploration activities that motivate horizontal R\&D alliances are also uncertain and frequently take time to materialize (March, 1991), making it difficult to develop effective contracts that cover the potential outcomes and their successful appropriation by partners (Carayannis and Alexander, 1999; Deeds and Hill, 1998).

The hypercompetitive environment in which many HTNFs operate often increases the risk of opportunistic partner behavior in horizontal alliances. Hypercompetition "is a condition of rapidly escalating competition based on price-quality positioning, competition to create new know-how and establish first-mover advantage, competition to protect or invade established product or geographic markets, and competition based on deep pockets and the creation of even deeper pocketed alliances" (D'Aveni, 1995: 46). In many high technology sectors a "winner-takes-it-all" scenario exists, and winning the competition for the creation of technological knowledge and know-how and its exploitation to gain a first-mover advantage is crucial for HTNFs' success (De Carolis and Deeds, 1999). Furthermore, in hypercompetitive environments knowledge protection through effective patenting is essential for HTNFs to limit or delay imitation of their products (Teece, 1986). Under such uncertain, dynamic and hostile conditions (D'Aveni, 1995) it is difficult for HTNFs to predict how the competitive relationship between the partners will develop in a co-opetitive, horizontal alliance. Safeguards against these risks are costly, often requiring thorough partner evaluation (Emden et al., 2006), extensive monitoring, and frequent renegotiation of alliance contracts. These problems can limit the resources the HTNF has for NPD activities. 
More specialized technological capabilities enable HTNFs to better mitigate the risks we have just discussed while maximizing the benefits of horizontal alliances in NPD activities. If the knowledge domains of both partners overlap, efficient learning in horizontal alliances becomes feasible only when firms have sufficient absorptive capacity to capture, assimilate and apply the new knowledge created through common R\&D efforts (Leonard-Barton, 1995). Competition between co-opeting partners may encourage mutually opportunistic behaviors that can turn a horizontal alliance into a "learning race" (Grindley and Mowery, 1994; Khanna et al., 1998). Reacting to the partner's learning effort, the HTNF may seek to enrich its own learning and knowledge from the partner. In turn, this can enhance the partner's motivation to learn. When this happens, partners may use the alliance only to learn quickly and expropriate as much knowledge as possible without being committed to the original good of the alliance. Success in a learning race, however, requires the HTNF to have specialized technological capabilities and sufficient absorptive capacity to quickly acquire the partner's knowledge needed for NPD.

Even if the knowledge domains of co-opeting partners do not overlap when the alliance is established, more specialized technological capabilities can counteract some of the risks arising from their partners' opportunistic behaviors. For example, firms may enter into alliances to acquire the partner's capabilities through organizational learning. Over the course of the alliance, the partner may build up knowledge and absorptive capacity in the focal firm's knowledge domain (Khanna et al., 1998). When a partner is trying to learn, the result may be a "competition for competence" (Hamel, 1991). Specialized technological capabilities based on highly sophisticated scientific techniques make it difficult for the partner to acquire the firm's knowledge and incorporate it into its own operations. Further, if the firm's scientists are leading experts in their area of specialization, their sophisticated and often tacit knowledge will be particularly difficult to acquire for co-opeting partners. This is likely to reduce the risk that partners will imitate the firm's scientific techniques and develop knowledge and absorptive capacity in that particular knowledge domain (Fig. 1). Therefore:

H2. The relationship between the number of horizontal alliances and product development is more positive when the internal technological capabilities of the high technology new firm are more specialized than when they are less specialized.

\subsection{Technological capabilities and vertical downstream alliances}

Vertical downstream alliances are partnerships formed between HTNFs and organizations that operate downstream of their value chains. In the biotechnology industry, for example, downstream alliance partners usually include large established pharmaceutical firms (Rothaermel and Deeds, 2004). Allying with an incumbent can enhance the HTNF's legitimacy by signaling its ability to develop valuable products (Stuart et al., 1999). These alliances help HTNFs to reinforce their market positions by avoiding costly and hazardous competition with incumbents (Gans and Stern, 2003).

In contrast to vertical upstream and horizontal alliances, acquiring technological knowledge from the alliance partner is usually not a primary motive for HTNFs to join downstream vertical alliances. HTNFs form downstream alliances to gain access to the complementary capabilities needed for NPD (Rothaermel and Deeds, 2004), especially the incumbents' legal and regulatory competence, manufacturing, distribution and marketing capabilities (Cullen and Dibner, 1993). Complementary capabilities might also include operational or non-technological knowledge of the downstream partner. For example, in the context of the biopharmaceutical industry this might include knowledge on how to conduct clinical trials, how to establish and operate large-scale manufacturing facilities for new products, and how to build up distribution channels and prepare for market entry. These capabilities are often costly to develop and alliances help the firm avoid making duplicative investments that may not pay off.

To benefit from downstream alliances and expedite NPD, HTNFs must effectively counteract the risk that - usually substantially larger and more experienced - downstream partners exploit their negotiating power at the expense of the HTNF. The loss of exploitation rights reduces HTNFs' ability to appropriate rents from new products and limit their ability to introduce additional product candidates based on IP associated with the jointly developed products. For instance, Lerner and Merges (1998) found that biotechnology firms which lack financial resources have little bargaining power in negotiating with an incumbent partner and therefore join alliances even if the majority of the control and product ownership rights are given to the incumbent. The same problem occurs when external financing is sparse during times of hostile equity markets. Under these conditions, HTNFs may have to give away much of their product ownership in exchange for cash they cannot easily access via the capital market (Lerner et al., 2003). Giving most control and product ownership rights to the incumbent, however, is inefficient for NPD because the research firm may not have the incentive to contribute to the success of the alliance. Not surprisingly, NPD alliances negotiated in hostile equity markets giving the incumbent firm significant control rights are more likely to fail (Lerner et al., 2003). For HTNFs, the loss of exploitation rights associated with the joint project and these failed alliances lead to the loss of the joint product and the resources needed to develop other product candidates, thereby reducing NPD.

Less specialized technological capabilities usually give HTNFs more flexibility and bargaining power in negotiating alliances and therefore partially escape their partner's excessive control. The HTNFs' bargaining power increases with the product's development stage (Aghion and Tirole, 1994) and advancing the product candidate along the value chain requires a more diverse set of technological capabilities (Henderson, 1993). For instance, NPD in biopharmaceutical firms is a multi-step process that requires a diversity of competencies in several disciplines (Sorensen and Stuart, 2000; Zhang et al., 2007). When negotiating alliance terms with a downstream partner, a broader set of technological capabilities will allow HTNFs to reduce asymmetric information because the HTNFs will have at least some understanding of the technologies used by the downstream partner to advance the product candidate. This understanding will enable HTNFs to better judge the contribution of the downstream 
partner in finalizing the NPD process and thus counteract the partner's attempts to appropriate an overly large part of the product's ownership (Lerner et al., 2003). Overall, as depicted in Fig. 1, HTNFs' less specialized technological capabilities can strengthen the HTNF's bargaining power and better counteract the risk of over-control in downstream alliances than highly specialized capabilities. Therefore:

H3. The relationship between the number of vertical downstream alliances and product development is more positive when the internal technological capabilities of the high technology new firm are less specialized than when they are more specialized.

\section{Data, method and analysis}

\subsection{Data collection and sample}

The biopharmaceutical sector provides an optimal setting for our study for several reasons. First, the development of products and technologies is strongly driven by HTNFs which are responsible for the development of the vast majority of drugs based on biotechnological methods. Second, due to the resource intensity of the development of biopharmaceuticals, HTNFs in this sector lack many of the capabilities and knowledge needed for NPD (Deeds and Hill, 1996). Third, because of HTNFs' resource scarcity, the building of networks to access collective knowledge is "the" key strategic task for the success of biotechnology and pharmaceutical firms (Powell et al., 2005; Haeussler, 2010b). Finally, to be successful in the competitive environment faced, entering into alliances of all three types of our model (upstream, horizontal and downstream) can provide benefits for biopharmaceutical HTNFs (Deeds and Hill, 1996).

HTNFs in the biopharmaceutical industry usually focus on the early steps of the modern pharmaceutical value chain (Deeds and Hill, 1996; Rothaermel and Deeds, 2004). The value chain starts with the identification and validation of a target gene or target protein, the malfunction of which is responsible for the development of a disease. Next, a potential drug candidate which interacts with the validated target is discovered. In the final part of the research process (the " $R$ " in pharmaceutical R\&D) drug candidates are optimized in a way that the interaction with their target is as strong and as specific as possible. The drug candidate then enters the development process (the "D" in pharmaceutical R\&D) starting with preclinical development. At this step, the drug candidate is analyzed in animal models and may be optimized again to circumvent undesired side effects. The drug is then tested in three subsequent clinical phases with healthy volunteers and patients suffering the targeted disease. Ultimately, if test results are supportive, the drug is approved by the regulatory authorities (DiMasi et al., 2003). HTNFs' role in this process typically includes the research-related steps, preclinical testing, and the first one or two clinical development steps before downstream alliances with pharmaceutical incumbents are entered to finalize the last and most expensive steps of the process and introduce the drug to the market (Rothaermel and Deeds, 2004).

Testing our hypotheses required measuring the alliance portfolio, technological capabilities and product development by HTNFs. Given that data on these variables were not available from public sources or commercial databases, we surveyed biotechnology firms in the UK and Germany, the largest and most developed biotech industries in Europe (Ernst and Young, 2008). The target population included all firms active in the biopharmaceutical sector, as defined by OECD (2005). We restricted our sample to this sector as there are significant differences in the degree of innovativeness, the level of R\&D spending, and the regulatory processes between the human biopharmaceutical sector and other sectors such as agricultural or veterinary biotechnology (Deeds and Hill, 1996). In identifying companies, we excluded those firms that were not founded in the two countries, firms that were subsidiaries of foreign firms, and those firms solely offering services or supplying products without conducting research. Firms were identified from several industry sources (e.g., Biocom, Dechema and Bio Commerce), regional databases like Erbi and Bio-M and internet searches. We checked the lists of firms targeted in the survey against our selection criteria with the help of biologists and biotechnologists. The final population consisted of 343 British and 346 German biotechnology firms. Data were collected in 2006.

Each firm received a personalized letter, addressed to the most senior manager, requesting their participation in the study. Prior to field data collection, we engaged industry experts from biotechnology associations as well as firms in designing the survey instrument. We also conducted 12 interviews to pre-test the questionnaire, leading us to revise the phrasing and sequencing of the questions. We conducted face-to-face interviews because biotechnology firm managers preferred this to mail and on-line surveys. Interviews also allowed us to clarify issues and better understand the choices HTNFs made. Interviews were conducted with 118 British and 162 German firms which agreed to participate in our study. This response rate of $47 \%$ for Germany and $34 \%$ for the UK provided us with a comprehensive sample of British and German biotechnology firms.

The "structured" interviews lasted approximately $35 \mathrm{~min}$ and were based on a preformatted questionnaire. Interviewers read the questions exactly as they appeared on the survey questionnaire and filled in the answers. The choice of answers to the question was mostly fixed (close-ended) in advance with the possibility to comment. Given that this study is designed to address issues of major strategic importance, we conducted the interviews with high-level managers. Eighty-nine percent of German interviews and $96 \%$ of British interviews were conducted with executive level interviewees. Furthermore, $73 \%$ and $65 \%$ of the German and British interviews respectively were conducted with the CEO/General Manager of the firm. The average interviewee had been working for the company for 6.5 years (UK) and 5.2 years (Germany).

Given our focus on NPD, we included only those firms that were active in the development of biopharmaceutical products. We therefore excluded 67 firms which were either not developing therapeutic, vaccine or diagnostic products or were solely providing contract research. Thus, firms developing platform technologies are not included in the sample. We chose these fields of activity 
for our study because firms operating in these fields have strongly used alliances to gain access to complementary resources and capabilities (George et al., 2001; De Carolis and Deeds, 1999; Shan et al., 1994; Zahra, 1996). Furthermore, 14 observations have been excluded because of missing variables. The final sample included 82 British and 117 German firms that are involved in NPD and provided the data requested. We pooled both samples because our testing for homogeneity of variance did not indicate significant country differences in NPD. ${ }^{4}$ Our final sample consisted of 199 firms.

\subsection{Dependent variable}

The study's dependent variable is a firm's new product development. Previous research highlights the long development time for biotechnological products, leading to only a few products having reached the market (e.g., Shan et al., 1994; Deeds and Hill, 1996; Deeds et al., 1999). Prior studies also suggest that an appropriate measure of the innovative output of biotechnology firms should consider products that are in regulatory trials and targeted to reach the market at some future date. Thus, our measure includes products on the market and products currently under development. Still, given our focus on relating alliance type and the degree of specialization of technological capabilities to the firm's innovativeness (not the success of acquiring products developed externally), we excluded products that have been licensed in, have been bought, or have entered the firm's product pipeline via take-over of another firm. Yet, including externally developed products in our measure would have increased the likelihood that alliances are developed solely to acquire those product candidates. This would have made the alliance a count variable (the "independent variable") measure being partly the same as the dependent variable. Thus, our dependent variable is operationalized as the sum of all internally developed products (i.e., therapeutics, vaccines and diagnostics) in a firm's pipeline that have successfully entered the preclinical and/or clinical stage as well as those products that have already entered the market. ${ }^{5}$ We obtained this variable from our survey of biotechnology managers.

\subsection{Independent variables}

Following our theoretical framework and Fig. 1, three variables capture a firm's alliance portfolio. Upstream alliances is a count variable of a firm's upstream vertical alliances with universities or publicly financed research organizations, those which focus on upstream activities of the value chain. Horizontal alliances is also a count variable of a firm's alliances with other biotechnology firms. Downstream alliances is a count variable of a firm's downstream vertical alliances with pharmaceutical firms.

The survey defined an alliance as the firm's active participation in joint projects. This definition excluded pure commissioning. To ensure accuracy, we asked interviewees to provide the number of formal and informal co-operative projects. ${ }^{6}$ Thus, we did not restrict the analysis to formal alliances because we did not know the extent to which formal alliances were more or less productive when compared to informal ones. Some prior research has shown that informal collaboration is important for a firm's innovativeness (e.g., von Hippel, 1987; Schrader, 1991).

Technological capabilities refer to the technical specialization of firms. We captured this variable by counting the number of biotechnological techniques a firm is able to use in the development of its products. A firm is often built around specific technical capabilities. Our measure thus reflects the technical capabilities at the outset of a firm. Consequently, we differentiated between DNA/RNA based on techniques, proteins and molecules, cell tissue culture and engineering as well as subcell techniques, process techniques, bioinformatics, and nanobiotechnology. These are the main areas of biotechnological techniques used in practice (OECD, 2005). We asked our interviewees which capability their firm uses and when it was built internally. Our use of the number of different "types" of technological capabilities is consistent with prior research (Mayer and Salomon, 2006).

\subsection{Control variables}

Our analyses also included the following variables as control variables because they could influence the firm's number of new products.

We controlled for the business model firms pursue. In biotechnology, a common strategy of young firms is to follow a dual business model. These firms offer contract research or services to third parties in order to finance their own R\&D activities. This "boot-strapping approach" may impede the rapid development of products (Haagen et al., 2007). We therefore included a dummy variable indicating whether a firm pursues such a dual business model or not.

Likewise, we controlled for firm age because older firms may have more products in development and on the market than younger firms (Deeds and Hill, 1996; Rothaermel and Deeds, 2004). We measured firm age by the log of the days from a firm's inception to December 31, 2005.

\footnotetext{
${ }^{4}$ We performed three tests for the equality of variances between British and German firms in NPD. The Levene test ( $\left.p=0.49\right)$ as well as Brown and Forsythe' tests replacing the mean in Levene's formula with the median $(p=0.93)$ and with the $10 \%$ trimmed mean $(p=0.90)$ were not significant and thus suggested that both samples could be pooled.

${ }^{5}$ We asked our interviewees to provide us with the number of products/technologies in the different development stages and products on the market that "have been developed internally."

${ }^{6}$ The exact wording of the question is "how many formal and informal co-operative projects is your company currently involved in with the following partners?" A) with universities and specialist research institutions, B) with other biotechnology firms and C) with pharmaceutical firms. We further note that "[w]e define co-operation as active participation in joint projects with other companies or non-commercial organizations. [...] [P]ure commissioning is not defined as co-operation."
} 
We also included the dummy variable VC financed to indicate whether a firm has received venture capital (VC) funds. Firms that have received this type of capital might have more products in the pipeline and on the market as compared to non-VC financed firms because they are likely to profit from services provided by their investors (Sapienza, 1992) and may have more money to support R\&D. Further, previous studies report the heterogeneous impact of being either VC financed or not. Some studies have shown that VC funded firms have a higher cash flow and sales growth (e.g., Jain and Kini, 1995). However, other studies do not find any significant effect of VC financing on firms' sales and employment growth (e.g., Buergel et al., 2002).

The analyses also controlled for the effect of R\&D intensity on NPD, using the number of RED employees. Researchers have examined the relationship between R\&D intensity and productivity (e.g., Pakes, 1985; Grabowski and Vernon, 1990). The most prominent measure for R\&D intensity is R\&D expenditures divided by company sales. However, because they are in their early development stage, many biotechnology firms do not have a positive revenue stream. Also, when they do, the revenue often comes from offering services, and not from the sale of their products (Haagen et al., 2007). Therefore, we use the log of the number of employees working in R\&D (i.e., chief scientific officer, researchers and developers, and technicians) as a proxy for R\&D intensity.

The study also controlled for the sector in which firms operate by including the dummy variable therapeutics in the analyses. Firms developing therapeutics are likely to have fewer products in development or on the market than firms developing diagnostics. Introducing a therapeutic drug to the market usually takes much longer and is more costly than introducing a diagnostic product.

The analyses controlled for firm location by using a dummy variable German firm to indicate whether the firm is located in Germany or in the UK. Though the literature on national innovation systems does not indicate country differences in the effects of alliance types or technological capabilities on NPD, to be conservative, we included this variable to account for potential differences. Table 1 summarizes the variables and the measures and related items from the interview questionnaire.

\section{Results}

\subsection{Descriptive statistics and correlations}

Table 2 reports the descriptive statistics for, and the correlations among, the study's variables. The average firm in the sample had 3.8 products in development or on the market, had entered into 4.1 vertical upstream alliances, 3.9 horizontal alliances, 2.2 vertical downstream alliances, and was able to use 2.5 biotechnological techniques. The average firm was also 8.2 years old (median: 6.1 years) and, on average, had 33 employees working in R\&D (median: 12). Forty-six percent of the firms were VC financed, $61 \%$ develop therapeutic drugs, 59\% of the sample was German, and 59\% pursued a dual business model.

Further, Table 2 indicates moderate to high correlations between the different types of alliances ranging from 0.53 (upstreamdownstream) to 0.72 (horizontal-downstream). This finding, however, is consistent with many other studies on alliances. For example, in their study of 132 biotechnology firms, Deeds and Hill (1996) report a correlation of 0.63 between the number of alliances with other biotechnology firms and pharmaceutical firms. Similarly, George et al. (2001) find a correlation of 0.75

Table 1

Variables and measures.

\begin{tabular}{|c|c|c|c|}
\hline \multirow[t]{2}{*}{ Variables } & \multirow[t]{2}{*}{ Measures in the survey } & \multicolumn{2}{|l|}{ Type of variable } \\
\hline & & Count variable & Dummy variable \\
\hline \multicolumn{4}{|l|}{ Dependent variable } \\
\hline Number of products & $\begin{array}{l}\text { Products on the market and currently under development } \\
\text { (subtracting number of in-licensed and acquired products as well } \\
\text { as products acquired through take-over of another firm). }\end{array}$ & $\mathrm{X}$ & \\
\hline \multicolumn{4}{|l|}{ Independent variables } \\
\hline Upstream alliances & $\begin{array}{l}\text { Number of alliances with universities or publicly financed } \\
\text { research organizations. }\end{array}$ & $\mathrm{X}$ & \\
\hline Horizontal alliances & Number of alliances with other biotechnology firms. & $\mathrm{X}$ & \\
\hline Downstream alliances & Number of alliances with pharmaceutical firms. & $\mathrm{X}$ & \\
\hline Technological capabilities & $\begin{array}{l}\text { Number of biotechnological techniques the firm is able to use out of } \\
\text { the following: DNA/RNA based technique, proteins and molecules, } \\
\text { cell tissue culture and engineering, subcell techniques, process techniques, } \\
\text { bioinformatics, nanobiotechnology. [Note: The date since the technique is } \\
\text { available in-house is taken into account]. }\end{array}$ & $\mathrm{X}$ & \\
\hline \multicolumn{4}{|l|}{ Control variables } \\
\hline Dual business model & $\begin{array}{l}=1 \text {, when the firm pursues a dual business model (offers contract } \\
\text { research or services to finance own R\&D activities), } 0 \text { otherwise. }\end{array}$ & & $\mathrm{X}$ \\
\hline Log Age & Logarithmic form of the days from a firm's inception to December 31, 2005. & $\mathrm{X}$ & \\
\hline Vcfinanced & $=1$, when the firm received VC financing, 0 otherwise. & & $\mathrm{X}$ \\
\hline $\log (\mathrm{R} \& \mathrm{D}$ employees $)$ & Logarithmic form of the number of employees in R\&D. & $\mathrm{X}$ & \\
\hline Therapeutics firm & $=1$, when the firm develops therapeutics or vaccines, 0 otherwise. & & $\mathrm{X}$ \\
\hline German firm & $=1$, when the firm is located in Germany, 0 otherwise & & $\mathrm{X}$ \\
\hline
\end{tabular}


Table 2

Descriptive statistics and correlations.

\begin{tabular}{|c|c|c|c|c|c|c|c|c|c|c|c|c|}
\hline Variables & Mean & S.D. & 1 & 2 & 3 & 4 & 5 & 6 & 7 & 8 & 9 & 10 \\
\hline 1. Number of products & 3.82 & 5.64 & 1 & & & & & & & & & \\
\hline 2. Technological capabilities & 2.54 & 1.52 & -0.08 & 1 & & & & & & & & \\
\hline 3. Upstream alliances & 4.07 & 7.46 & 0.08 & 0.22 & 1 & & & & & & & \\
\hline 4. Horizontal alliances & 3.88 & 8.72 & 0.05 & 0.13 & 0.65 & 1 & & & & & & \\
\hline 5. Downstream alliances & 2.22 & 5.66 & 0.06 & 0.17 & 0.53 & 0.72 & 1 & & & & & \\
\hline 6. German Firm & 0.59 & n.a. & 0.09 & -0.14 & $0.21 \bullet$ & -0.06 & -0.05 & 1 & & & & \\
\hline 7. Log(age in days) & 7.78 & 0.65 & 0.26 & -0.01 & 0.1 & 0.26 & 0.23 & $-0.09 \diamond$ & 1 & & & \\
\hline 8. VCfinanced & 0.46 & n.a. & $0.12 \bullet$ & 0.23 & $0.10 \diamond$ & $0.10 \bullet$ & $0.15 \bullet$ & $-0.04 \diamond$ & 0.09 & 1 & & \\
\hline 9. $\log (\mathrm{R} \& \mathrm{D}$ employees) & 2.69 & 1.09 & 0.1 & 0.34 & 0.34 & 0.32 & 0.39 & 0.03 & 0.38 & 0.31 & 1 & \\
\hline 10. Therapeutics firm & 0.51 & n.a. & $-0.07 \bullet$ & $0.10 \bullet$ & $0.12 \diamond$ & 0.06 & $0.20 \bullet$ & $0.07 \diamond$ & -0.13 & $0.09 \diamond$ & -0.02 & 1 \\
\hline 11. Dual business model & 0.59 & n.a. & -0.07 & $-0.001 \bullet$ & $0.08 \bullet$ & $0.08 \bullet$ & $0.13 \bullet$ & $0.04 \diamond$ & -0.09 & $-0.06 \diamond$ & 0.005 & $-0.12 \diamond$ \\
\hline
\end{tabular}

Note: Pearson product moment correlation unless otherwise stated; $\diamond$ Cramers' V; $\diamond$ Spearman rank correlation coefficient. $N=199$.

between the number of horizontal and vertical alliances in their study of 143 biotechnology firms. Studying 352 biotechnology firms Rothaermel and Deeds (2004) report a correlation of 0.52 between exploration (upstream) and exploitation (downstream) alliances. McKelvey (1996) explains this observation arguing that the economics of biotechnology are either a small-firm phenomenon or a complex division of labor along the value chain, where firms co-specialize in different parts of the value chain. ${ }^{7}$

\subsection{Poisson regression analysis}

Table 3 reports the results on the determinants of the number of products on the market and products currently under development. The preponderance of small values and discrete nature of the dependent variable suggests using a log linear Poisson model. Poisson probabilities are widely used to model the number of occurrences of an event (Greene, 2003; Cameron and Trivedi, 1998). We first entered the variable indicating the technological capabilities of a firm and the control variables (Model M1). Next, we added the three variables capturing the number of upstream, horizontal and downstream alliances, respectively, and their interactions with the technological capabilities variable (M2-M7). Model 8 contains all alliance variables but no interactions. In Models M9-M11 we add interactions of upstream, horizontal, and downstream alliances, respectively. Model M12 includes all three alliance variables and all interaction terms.

Models in Table 3 indicate that the sign and significance of the interaction variables are robust across the Poisson models. Specifically, there is a negative and significant interaction between upstream alliances and technological capabilities in models M3 (coefficient $=-0.012, p<0.01$ ) and M9 (coefficient $=-0.008, p<0.05$ ). The interaction is also significant in the full model M12, albeit only marginally (coefficient $=-0.007, p<0.10$ ). This provides some support for Hypothesis H1 positing that the relationship between upstream alliances and NPD is more positive when the number of technological capabilities decreases (i.e., their specialization increases).

There is a negative interaction between horizontal alliances and technological capabilities. This interaction is non-significant in M5, but it becomes significant in M10 (coefficient $=-0.010, p<0.01$ ) and highly significant in the full model (M12: coefficient $=-0.017, p<0.001)$. This interaction indicates that the relationship between horizontal alliances and NPD is more positive when the number of technological capabilities decreases (i.e., their specialization increases). This supports Hypothesis $\mathrm{H} 2$, depicted in Fig. 1. There is also a positive and highly significant interaction between downstream alliances and technological capabilities in all models (M7: coefficient $=0.037, p<0.001$; M11: coefficient $=0.032, p<0.001$; M12: coefficient $=0.037$, $p<0.001)$. These results show that the relationship between downstream alliances and NPD is more positive when the number of technological capabilities increases (i.e., their specialization decreases), thereby supporting Hypothesis H3 (see Fig. 1).

\subsection{Robustness checks and endogeneity}

We conducted additional tests to establish the robustness of the results we have just presented. In conducting these tests, we considered the issue of endogeneity in our model especially regarding the firm's technological capabilities and strategic alliances.

It is possible that a HTNF's alliances trigger or enhance the development of technological capabilities (e.g., if the knowledge acquired in the alliances leads to the development of scientific techniques, the foundation of technological capabilities in our study). These capabilities may improve the firm's rate of product development. To address this issue and test whether our results are driven by the proposed mechanism, we made use of the fact that our data set lists the date when the firm has built a specific technological capability. This allows us to identify those capabilities which the firm possessed at the time it was founded. While path dependency arguments would suggest that these capabilities are highly influential for the future technological path of the firm (Teece et al., 1997), they are exogenous to our model. If we calculate the full model with these initial technological

\footnotetext{
7 Furthermore, a discriminant analysis extracted two dimensions of alliance activities for NPD. The first significant dimension reflects a horizontal versus vertical dimension while the second is an upstream versus downstream dimension. These results provide further justification for our distinction among upstream, vertical and downstream alliances.
} 
Table 3

Results of Poisson model. Dependent variable: number of products; estimation method: Poisson; IV designates an instrumented model.

\begin{tabular}{|c|c|c|c|c|c|c|c|c|c|c|c|c|c|c|}
\hline Coefficient & M1 & M2 & M3 & M4 & M5 & M6 & M7 & M8 & M9 & M10 & M11 & M12 & $\begin{array}{l}\text { M13 TCs at } \\
\text { founding }\end{array}$ & M14 IV \\
\hline $\begin{array}{c}\text { Technological } \\
\text { capabilities }\end{array}$ & $\begin{array}{l}-0.091^{* *} \\
(0.028)\end{array}$ & $\begin{array}{l}-0.0955^{* * *} \\
(0.029)\end{array}$ & $\begin{array}{l}-0.062^{*} \\
(0.031)\end{array}$ & $\begin{array}{l}-0.090^{* *} \\
(0.028)\end{array}$ & $\begin{array}{l}-0.096 * * \\
(0.030)\end{array}$ & $\begin{array}{l}-0.092^{* *} \\
(0.028)\end{array}$ & $\begin{array}{l}-0.161^{* * *} \\
(0.031)\end{array}$ & $\begin{array}{l}-0.117^{* * *} \\
(0.029)\end{array}$ & $\begin{array}{l}-0.092^{* *} \\
(0.031)\end{array}$ & $\begin{array}{l}-0.097^{* *} \\
(0.030)\end{array}$ & $\begin{array}{l}-0.169^{* * *} \\
(0.031)\end{array}$ & $\begin{array}{l}-0.124^{* * *} \\
(0.033)\end{array}$ & $\begin{array}{l}-0.069+ \\
(0.038)\end{array}$ & $\begin{array}{l}-0.172^{* *} \\
(0.060)\end{array}$ \\
\hline Upstream alliances & & $\begin{array}{l}0.006 \\
(0.004)\end{array}$ & $\begin{array}{l}0.051^{* *} \\
(0.017)\end{array}$ & & & & & $\begin{array}{l}0.029^{* * * *} \\
(0.007)\end{array}$ & $\begin{array}{l}0.058^{* * *} \\
(0.015)\end{array}$ & $\begin{array}{l}0.039 * * * \\
(0.007)\end{array}$ & $\begin{array}{l}0.025^{* * *} \\
(0.007)\end{array}$ & $\begin{array}{l}0.067^{* * *} \\
(0.015)\end{array}$ & $\begin{array}{l}0.067^{* * *} \\
(0.011)\end{array}$ & $\begin{array}{l}-0.109^{* *} \\
(0.037)\end{array}$ \\
\hline $\begin{array}{l}\text { Upstream alliances x } \\
\text { Technological } \\
\text { capabilities }\end{array}$ & & & $\begin{array}{l}-0.012^{* *} \\
(0.004)\end{array}$ & & & & & & $\begin{array}{l}-0.008^{*} \\
(0.004)\end{array}$ & & & $\begin{array}{l}-0.007+ \\
(0.004)\end{array}$ & $\begin{array}{l}-0.018^{* *} \\
(0.006)\end{array}$ & $\begin{array}{l}-0.014 \\
(0.013)\end{array}$ \\
\hline Horizontal alliances & & & & $\begin{array}{l}-0.007^{*} \\
(0.004)\end{array}$ & $\begin{array}{l}-0.014 \\
(0.011)\end{array}$ & & & $\begin{array}{l}-0.038^{* * *} \\
(0.007)\end{array}$ & $\begin{array}{l}-0.037^{* * *} \\
(0.007)\end{array}$ & $\begin{array}{l}-0.013 \\
(0.011)\end{array}$ & $\begin{array}{l}-0.024^{* *} \\
(0.007)\end{array}$ & $\begin{array}{l}0.027+ \\
(0.014)\end{array}$ & $\begin{array}{l}0.008 \\
(0.013)\end{array}$ & $\begin{array}{l}0.175^{*} \\
(0.071)\end{array}$ \\
\hline Horizontal alliances $\mathrm{x}$ & & & & & 0.002 & & & & & $-0.010^{* *}$ & & $-0.017^{* * *}$ & $-0.019^{*}$ & $-0.080^{* * *}$ \\
\hline $\begin{array}{l}\text { Technological } \\
\text { capabilities }\end{array}$ & & & & & $(0.003)$ & & & & & $(0.004)$ & & $(0.004)$ & $(0.008)$ & $(0.016)$ \\
\hline Downstream alliances & & & & & & $\begin{array}{l}0.003 \\
(0.006)\end{array}$ & $\begin{array}{l}-0.142^{* * *} \\
(0.029)\end{array}$ & $\begin{array}{l}0.026^{* *} \\
(0.009)\end{array}$ & $\begin{array}{l}0.026^{* *} \\
(0.009)\end{array}$ & $\begin{array}{l}0.030^{* * * *} \\
(0.009)\end{array}$ & $\begin{array}{l}-0.116^{* *} \\
(0.037)\end{array}$ & $\begin{array}{l}-0.136^{* * *} \\
(0.035)\end{array}$ & $\begin{array}{l}-0.115^{* * *} \\
(0.020)\end{array}$ & $\begin{array}{l}-0.311^{*} \\
(0.135)\end{array}$ \\
\hline Downstream alliances $\mathrm{x}$ & & & & & & & $0.037^{* * *}$ & & & & $0.032^{* * *}$ & $0.037^{* * *}$ & $0.051^{* * *}$ & $0.184^{* * *}$ \\
\hline $\begin{array}{l}\text { Technological } \\
\text { capabilities }\end{array}$ & & & & & & & $(0.007)$ & & & & $(0.008)$ & $(0.007)$ & $(0.007)$ & $(0.027)$ \\
\hline Dual Business Model & $\begin{array}{l}-0.230^{* *} \\
(0.074)\end{array}$ & $\begin{array}{l}-0.222^{* *} \\
(0.074)\end{array}$ & $\begin{array}{l}-0.237^{* *} \\
(0.075)\end{array}$ & $\begin{array}{l}-0.241^{* *} \\
(0.074)\end{array}$ & $\begin{array}{l}-0.235^{* *} \\
(0.075)\end{array}$ & $\begin{array}{l}-0.230^{* *} \\
(0.074)\end{array}$ & $\begin{array}{l}-0.166^{*} \\
(0.075)\end{array}$ & $\begin{array}{l}-0.256^{* * *} \\
(0.075)\end{array}$ & $\begin{array}{l}-0.259^{* * *} \\
(0.075)\end{array}$ & $\begin{array}{l}-0.288^{* * *} \\
(0.076)\end{array}$ & $\begin{array}{l}-0.200^{* *} \\
(0.076)\end{array}$ & $\begin{array}{l}-0.215^{* *} \\
(0.077)\end{array}$ & $\begin{array}{l}-0.300^{* * *} \\
(0.077)\end{array}$ & $\begin{array}{l}-0.179^{*} \\
(0.078)\end{array}$ \\
\hline Log Age & $\begin{array}{l}0.541^{* * *} \\
(0.062)\end{array}$ & $\begin{array}{l}0.538^{* * * *} \\
(0.062)\end{array}$ & $\begin{array}{l}0.554^{* * * *} \\
(0.063)\end{array}$ & $\begin{array}{l}0.560^{* * * *} \\
(0.063)\end{array}$ & $\begin{array}{l}0.566^{* * *} \\
(0.063)\end{array}$ & $\begin{array}{l}0.538^{* * * *} \\
(0.062)\end{array}$ & $\begin{array}{l}0.538^{* * * *} \\
(0.063)\end{array}$ & $\begin{array}{l}0.591^{* * * *} \\
(0.063)\end{array}$ & $\begin{array}{l}0.600^{* * * *} \\
(0.063)\end{array}$ & $\begin{array}{l}0.574^{* * * *} \\
(0.063)\end{array}$ & $\begin{array}{l}0.567^{* * * *} \\
(0.063)\end{array}$ & $\begin{array}{l}0.536^{* * *} \\
(0.065)\end{array}$ & $\begin{array}{l}0.495^{* * * *} \\
(0.065)\end{array}$ & $\begin{array}{l}0.424^{* * * *} \\
(0.084)\end{array}$ \\
\hline Vcfinanced & $\begin{array}{l}-0.088 \\
(0.078)\end{array}$ & $\begin{array}{l}-0.099 \\
(0.078)\end{array}$ & $\begin{array}{l}-0.092 \\
(0.079)\end{array}$ & $\begin{array}{l}-0.070 \\
(0.078)\end{array}$ & $\begin{array}{l}-0.070 \\
(0.078)\end{array}$ & $\begin{array}{l}-0.089 \\
(0.078)\end{array}$ & $\begin{array}{l}-0.066 \\
(0.079)\end{array}$ & $\begin{array}{l}-0.049 \\
(0.079)\end{array}$ & $\begin{array}{l}-0.050 \\
(0.079)\end{array}$ & $\begin{array}{l}-0.039 \\
(0.079)\end{array}$ & $\begin{array}{l}-0.044 \\
(0.079)\end{array}$ & $\begin{array}{l}-0.050 \\
(0.079)\end{array}$ & $\begin{array}{l}-0.196^{*} \\
(0.080)\end{array}$ & $\begin{array}{l}-0.155 \\
(0.124)\end{array}$ \\
\hline Log(R\&D employees) & $\begin{array}{l}0.068+ \\
(0.037)\end{array}$ & $\begin{array}{l}0.047 \\
(0.040)\end{array}$ & $\begin{array}{l}0.051 \\
(0.040)\end{array}$ & $\begin{array}{l}0.095^{*} \\
(0.039)\end{array}$ & $\begin{array}{l}0.091^{*} \\
(0.040)\end{array}$ & $\begin{array}{l}0.060 \\
(0.041)\end{array}$ & $\begin{array}{l}0.072+ \\
(0.041)\end{array}$ & $\begin{array}{l}0.052 \\
(0.041)\end{array}$ & $\begin{array}{l}0.052 \\
(0.041)\end{array}$ & $\begin{array}{l}0.057 \\
(0.041)\end{array}$ & $\begin{array}{l}0.061 \\
(0.041)\end{array}$ & $\begin{array}{l}0.079 \\
(0.041)\end{array}$ & $\begin{array}{l}0.086^{*} \\
(0.040)\end{array}$ & $\begin{array}{l}0.307^{*} \\
(0.141)\end{array}$ \\
\hline Therapeutics firm & $\begin{array}{l}-0.663^{* * *} \\
(0.077)\end{array}$ & $\begin{array}{l}-0.649^{* * *} \\
(0.077)\end{array}$ & $\begin{array}{l}-0.662^{* * *} \\
(0.078)\end{array}$ & $\begin{array}{l}-0.679 * * * \\
(0.077)\end{array}$ & $\begin{array}{l}-0.670^{* * *} \\
(0.079)\end{array}$ & $\begin{array}{l}-0.664^{* * *} \\
(0.077)\end{array}$ & $\begin{array}{l}-0.608^{* * *} \\
(0.077)\end{array}$ & $\begin{array}{l}-0.728^{* * *} \\
(0.080)\end{array}$ & $\begin{array}{l}-0.725^{* * *} \\
(0.080)\end{array}$ & $\begin{array}{l}-0.782^{* * * *} \\
(0.083)\end{array}$ & $\begin{array}{l}-0.652^{* * *} \\
(0.082)\end{array}$ & $\begin{array}{l}-0.699^{* * * *} \\
(0.084)\end{array}$ & $\begin{array}{l}-0.634^{* * *} \\
(0.082)\end{array}$ & $\begin{array}{l}-0.482^{*} \\
(0.216)\end{array}$ \\
\hline German firm & $\begin{array}{l}0.180^{*} \\
(0.077)\end{array}$ & $\begin{array}{l}0.149+ \\
(0.081)\end{array}$ & $\begin{array}{l}0.110 \\
(0.082)\end{array}$ & $\begin{array}{l}0.190^{*} \\
(0.077)\end{array}$ & $\begin{array}{l}0.181^{*} \\
(0.078)\end{array}$ & $\begin{array}{l}0.178^{*} \\
(0.077)\end{array}$ & $\begin{array}{l}0.187^{*} \\
(0.078)\end{array}$ & $\begin{array}{l}0.080 \\
(0.080)\end{array}$ & $\begin{array}{l}0.048 \\
(0.083)\end{array}$ & $\begin{array}{l}0.084 \\
(0.081)\end{array}$ & $\begin{array}{l}0.110 \\
(0.081)\end{array}$ & $\begin{array}{l}0.081 \\
(0.085)\end{array}$ & $\begin{array}{l}0.049 \\
(0.084)\end{array}$ & $\begin{array}{l}0.514^{* * * *} \\
(0.124)\end{array}$ \\
\hline Constant & $\begin{array}{l}-2.520^{* * *} \\
(0.507)\end{array}$ & $\begin{array}{l}-2.441^{* * *} \\
(0.511)\end{array}$ & $\begin{array}{l}-2.665^{* * *} \\
(0.522)\end{array}$ & $\begin{array}{l}-2.715^{* * *} \\
(0.514)\end{array}$ & $\begin{array}{l}-2.738^{* * *} \\
(0.515)\end{array}$ & $\begin{array}{l}-2.477^{* * *} \\
(0.515)\end{array}$ & $\begin{array}{l}-2.389^{* * *} \\
(0.519)\end{array}$ & $\begin{array}{l}-2.758^{* * *} \\
(0.512)\end{array}$ & $\begin{array}{l}-2.896^{* * *} \\
(0.520)\end{array}$ & $\begin{array}{l}-2.690^{* * *} \\
(0.514)\end{array}$ & $\begin{array}{l}-2.530^{* * *} \\
(0.518)\end{array}$ & $\begin{array}{l}-2.482^{* * *} \\
(0.530)\end{array}$ & $\begin{array}{l}-2.226^{* * *} \\
(0.532)\end{array}$ & $\begin{array}{l}-2.212^{* * *} \\
(0.651)\end{array}$ \\
\hline Observations & 199 & 199 & 199 & 199 & 199 & 199 & 199 & 199 & 199 & 199 & 199 & 199 & 199 & 199 \\
\hline Pseudo Rsquared & 0.157 & 0.158 & 0.162 & 0.159 & 0.159 & 0.157 & 0.182 & 0.176 & 0.179 & 0.180 & 0.190 & 0.204 & 0.21 & 0.213 \\
\hline chi2 & 260.0 & 261.8 & 269.0 & 264.1 & 264.5 & 260.2 & 301.2 & 292.7 & 297.0 & 299.3 & 315.3 & 338.0 & 348.8 & 353 \\
\hline ll & -699.4 & -698.5 & -694.9 & -697.3 & -697.1 & -699.3 & -678.8 & -683.1 & -680.9 & -679.8 & -671.8 & -660.4 & -655 & -652.9 \\
\hline
\end{tabular}

Standard errors in parentheses, ${ }^{* * *} p<0.001,{ }^{* *} p<0.01,{ }^{*} p<0.05,{ }^{+} p<0.1$. The IV model (M14) represents only the second stage model. The first results are available from the authors upon request. 
capabilities instead of the capabilities the firm had at the time of our field work, we find that the results change little (compare models M12 and M13 in Table 3). Specifically, the interaction between upstream alliances and initial technological capabilities is negative and significant (coefficient $=-0.018, p<0.01$ ). Moreover, the interaction between horizontal alliances and initial technological capabilities is significant and negative (coefficient $=-0.019, p<0.05$ ). The interaction between upstream alliances and initial technological capabilities is positive and significant (coefficient $=0.051, p<0.001$ ). This indicates that endogeneity of technological capabilities is not a serious problem in the analyses we reported earlier in this paper.

Some previous studies highlight the endogenous character of firms' alliances (e.g., Gulati, 1998). For instance, the technological capabilities of a firm may drive its alliances, which in turn impact its NPD. Alternatively, high rates of NPD may make a HTNF an attractive alliance partner and thus influence its alliance formation. To address the endogenous character of upstream, horizontal, and downstream alliances, we use a count-data instrumental variables model developed by Mullahy (1997). This model is a generalized method of moments (GMM) model for count data with endogenous variables - an instrumented Poisson model. Angrist (2001) shows that this model provides consistent estimates. In conducting our analyses, we use four exogenous variables as instruments for the number of alliances variables.

We use three variables representing the level of incoming knowledge flows from external sources of information to indicate the exogenous available spillover pool (Cassiman and Veugelers, 2002). In the survey, we asked our interviewees to what extent three external sources of information are important for their R\&D activity on a five-point Likert scale ranging from not important (1) to extremely important (5). The external sources of information are a) universities (upstream alliance partners), b) customers including collaborating customers (downstream alliance partners) and c) competitors in the same field of activity (horizontal alliance partners). On average, our interviewees rate universities as important sources of information for R\&D (mean: 3.9); this was higher than customers (3.7) and competing firms (3.0) as sources of information. Furthermore, as a fourth instrumental variable, we use a dummy variable indicating whether the firm is a spin-out of a university or a research institute. The R\&D of these spin-outs is more likely related to basic research than the R\&D of other firms. Cohen and Levinthal (1990) argue that the type of R\&D influences the firm's capacity for profiting from external knowledge (as knowledge gained through alliances). Since both our models pass the Sargan $(p=0.49)$ and the Basman $(p=0.51)$ test of overidentification, it appears that there is sufficient validity of our instruments.

Model 14 in Table 3 presents the results, taking the endogeneity of alliance variables into account. Comparing the coefficients of our interaction variables in the full un-instrumented model (M12) with the instrumented model (M14), we find that the interaction between upstream alliances and technological capabilities is still negative, but its significance diminishes (coefficient $=-0.014, p>0.1$ ). This indicates that the weak support for $\mathrm{H} 1$ is not robust when we take endogeneity of upstream alliance variables into account. The interaction between horizontal alliances and technological capabilities also is negative and highly significant (coefficient $=-0.080, p<0.001$ ), providing additional support for $\mathrm{H} 2$ from the instrumented model. The interaction between downstream alliance and technological capabilities is positive and highly significant (coefficient $=0.184$, $p<0.001$ ), indicating that support for $\mathrm{H} 3$ is also robust. Finally, the sign and significance of the other control variables remain to a large extent robust in the instrumented model.

Overall, our robustness tests of endogeneity suggest that our basic premise holds, although the interaction related to H1 shows the same sign but is not significant in the instrumented Poisson model. Clearly, the results support the study's three hypotheses, but support for $\mathrm{H} 1$ is weak.

\section{Discussion}

A large body of research has focused on the role of strategic alliances in giving partnering firms superior value relative to alternative organizational forms, even though alliances are frequently prone to failure (Madhok and Tallman, 1998). One of the key areas where alliance members often benefit is NPD (Rothaermel and Deeds, 2004), a major source of revenue and growth (Baum et al., 2000). However, NPD is risky because firms do not always have the requisite internal capabilities and frequently have to obtain them from external sources such as alliances. In this paper, we have proposed that different types of alliances give the firm differential access to different types of capabilities (Rothaermel and Deeds, 2006). This is especially the case among HTNFs that often do not have the resources and experiences to build the right mix of capabilities they need on their own. Applying the capabilities perspective, we have explored how upstream, downstream and horizontal alliances impact HTNFs where NPD is essential to these firms' survival, growth and profitability. Building on the capabilities perspective, we have also proposed that this effect depends on the degree of specialization of HTNFs' internal technological capabilities. Table 4 summarizes how our results compare to previous studies, which we discuss next.

Our research underscores the importance of internal technological capabilities in determining HTNFs' potential benefits and risks when they join strategic alliances. The results extend the literature showing that alliance success depends on a firm's alliance experience (Hoang and Rothaermel, 2005) and the munificence of its financing environment (Lerner et al., 2003). Rothaermel and Deeds (2006) have also shown that young biotechnology firms with considerable alliance experience stand to gain more benefits from entering into additional alliances (up to a certain point) than firms with more limited experience. Our study focuses on HTNFs' internal technological capabilities and shows that the degree of specialization of these capabilities significantly influences the contribution of strategic alliances to their NPD.

Most prior research has examined individual alliances' level of analysis, showing that alliances fail because of opportunistic partner behavior (Deeds and Hill, 1998) and misallocation of control rights (Lerner et al., 2003). However, prior studies have neglected the effect of alliance failure on organizational performance. At the organizational level some studies have argued that, 
Table 4

Summary comparison between this study's and previous work on alliances.

\begin{tabular}{|c|c|c|c|}
\hline \multirow[t]{2}{*}{ Previous studies } & \multicolumn{3}{|l|}{ This study } \\
\hline & Extending & Supporting & Contradicting \\
\hline \multicolumn{4}{|l|}{ Alliances in general } \\
\hline (Hoang and Rothaermel, 2005) & $\mathrm{X}$ & & \\
\hline (Lerner et al., 2003) & $\mathrm{X}$ & & \\
\hline (Deeds and Hill, 1996) & $X$ & & \\
\hline (Rothaermel and Deeds, 2006) & $\mathrm{X}$ & & \\
\hline \multicolumn{4}{|l|}{ Upstream vertical alliances } \\
\hline (Rothaermel and Deeds, 2006) & $\mathrm{X}$ & & $\mathrm{X}$ \\
\hline (Zucker et al., 2002) & & $\mathrm{X}$ & \\
\hline (Oliver and Liebeskind, 1998) & & $\mathrm{X}$ & \\
\hline (Powell et al., 1996) & & $\mathrm{X}$ & \\
\hline (Owen-Smith and Powell, 2004) & & $\mathrm{X}$ & \\
\hline (George et al., 2001) & $\mathrm{X}$ & & $\mathrm{X}$ \\
\hline \multicolumn{4}{|l|}{ Horizontal alliances } \\
\hline (Rothaermel and Deeds, 2006) & $\mathrm{X}$ & & $\mathrm{X}$ \\
\hline (Baum et al., 2000) & $\mathrm{X}$ & $(\mathrm{X})$ & \\
\hline Deeds and Hill (1999) & $\mathrm{X}$ & $\mathrm{X}$ & \\
\hline (Mowery et al., 1996) & & $\mathrm{X}$ & \\
\hline (Park and Russo, 1996) & & $\mathrm{X}$ & \\
\hline (Khanna et al., 1998) & & $\mathrm{X}$ & \\
\hline (Gnyawali and Madhavan, 2001) & & $\mathrm{X}$ & \\
\hline \multicolumn{4}{|l|}{ Downstream vertical alliances } \\
\hline (Rothaermel and Deeds, 2006) & $\mathrm{X}$ & & $\mathrm{X}$ \\
\hline (Gulati and Higgins, 2003) & $\mathrm{X}$ & $(\mathrm{X})$ & \\
\hline (George et al., 2001) & $\mathrm{X}$ & $(\mathrm{X})$ & \\
\hline (Lerner and Merges, 1998) & & $(\mathrm{X})$ & \\
\hline (Lerner et al., 2003) & & $(\mathrm{X})$ & \\
\hline
\end{tabular}

Note: $(\mathrm{X})$ indicates partial support.

for HTNFs, the more alliances the better (e.g., Shan et al., 1994). Only few researchers have investigated the negative effect of adding a new alliance, finding curvilinear relationships between either the total number of alliances (Deeds and Hill, 1996) or the number of upstream, horizontal, and vertical alliances (Rothaermel and Deeds, 2006) and NPD. Thus, HTNFs may not have sufficient financial and managerial resources to manage the complexity of a large alliance portfolio, leading to diminishing and finally negative returns from joining new alliances. Though we have tested for curvilinear relationships, we found limited support only in the case of horizontal alliances. The significance of this effect disappeared after interaction effects were considered. ${ }^{8}$

When we consider the interaction effects of technological capabilities with individual types of alliances, our results challenge some previous findings in the biotechnology industry. For instance, with respect to upstream alliances, several prior studies have emphasized the benefits of upstream alliances for HTNFs (Zucker et al., 2002; Rothaermel and Deeds, 2006; Oliver and Liebeskind, 1998; Powell et al., 1996; Owen-Smith and Powell, 2004). This is consistent with our finding that there is a significant and positive main effect for the number of upstream alliances on NPD in most models of our regression analysis (as reported in Table 3, models M3, M8, M9, M10, M11, M12, and M13). Interestingly, however, George et al. (2002) report that new biotechnology firms that have links with universities do not develop more products than firms without these linkages. Our study suggests one potential reason for this finding - the effect of university linkages on NPD depends on the specialization of the HTNF's technological capabilities. Hence, only when technological capabilities are specialized and the HTNF has a deep understanding of the university's research, it will have enough absorptive capacity to capitalize on the scientific knowledge created by its alliance partner. Otherwise, the HTNF may be unable to integrate this knowledge and effectively monitor its partner's R\&D activities leaving it vulnerable to the risk of opportunistic behavior (Bower, 1992). Even if knowledge domains of alliance partners do not overlap and the HTNF's primary alliance objective is not the acquisition of new knowledge but only accessing the partner's technology, reputation in the scientific community based on technological specialization (Hicks, 1995) may protect HTNFs from upstream partners' opportunism. Clearly, analyzing these interaction terms is necessary to better understand the effect of university alliances on a firm's NPD.

The results also indicate that horizontal alliances and co-opetition may not necessarily be as hazardous as sometimes assumed in the literature. For example, Baum et al. (2000) found a negative effect of horizontal alliances on biotechnology firms'

\footnotetext{
${ }^{8}$ Several factors might have contributed to these differences. Specifically, in our research the dependent variable considers only products that have been developed internally by the firm. We have also gathered alliance data by administering a survey which allows us to take formal and informal alliances into account, whereas the studies cited used only formal alliances as reported in the Bioscan database. In addition, our sample consists of German and UK biotechnology firms whereas firms listed in Bioscan are mainly US-based.
} 
patenting activities, and revenue and R\&D spending growth. Other studies have also highlighted the danger of co-opetition because competition among alliance partners may become more prevalent than cooperation (e.g., Deeds and Hill, 1999; Mowery et al., 1996; Park and Russo, 1996; Khanna et al., 1998; Gnyawali and Madhavan, 2001). Supporting these arguments, we find a negative and significant main effect of the number of horizontal alliances on NPD in models where interactions between technological capabilities and horizontal alliances are excluded (Table 3, models M4, M8, M9, and M11). Still, the picture changes when we consider interaction terms: the negative main effect relationship becomes either non-significant (models M5, M10, and M13) or even (marginally) significant and positive (models M12 and M14).

It appears that for HTNFs a more specialized capability base mitigates the risks and/or enhances the upside potential of horizontal alliances in a way that makes these alliances more beneficial for NPD. Consistent with the literature on co-opetition (Brandenburger and Nalebuff, 1996), when the firm's scientific reputation is tied to technological specialization, it allows for a better negotiation of alliance contracts and protects from partners' opportunism. Alternatively, specialization based on highly sophisticated technologies may protect the HTNF's knowledge base from partner's expropriation efforts, a key to success in coopetitive alliances (Hamel et al., 1989; Khanna et al., 1998). Considering interactions between a HTNF's technology base and its horizontal alliances appears necessary to better appreciate the effect of co-opetition on NPD.

Some scholars have also highlighted the beneficial effect of vertical downstream alliances on new firms' products on the market (George et al., 2001). One exception is the work by Lerner and colleagues (Lerner and Merges, 1998; Lerner et al., 2003), who identified cash constraints and hostile financing environments as potentially pressuring biotechnology firms to join downstream alliances under unfavorable conditions and even give away much of their products' future. Gulati and Higgins (2003) found no relationship between downstream alliances and a successful Initial Public Offering (IPO) among new biotechnology firms. Thus, existing literature is unclear of whether downstream alliances are overall beneficial for HTNFs or not.

Our findings highlight the complexity of downstream alliances' contribution to firm performance. For example, consistent with Gulati and Higgins (2003), we do not find a main effect of downstream alliances on NPD in Model M5. However, consistent with George et al. (2001), we find a significant and positive relationship between downstream alliances and NPD in most models where only the main effect is considered (models M8, M9, and M10). Yet, introducing the interaction term between technological capabilities and downstream alliances provides a more detailed and accurate picture of the relationships at hand. In these models, the main effect is significant and negative, while interaction terms are significant and positive. This suggests that the contribution of downstream alliances to NPD is contingent on the firm's technological specialization. Thus, only a subset of biotechnology firms (i.e., those with less specialized technological capabilities) benefit from this type of alliance in their NPD and, perhaps, subsequent IPO valuation. For HTNFs with more specialized technological capabilities, downstream alliances are not as beneficial (or even detrimental - see Lerner and Merges, 1998; Lerner et al., 2003) to NPD.

Our results are best interpreted in the broader context of the capabilities-based view of alliance formation. As noted, this perspective emphasizes that firms enter into alliances to gain access to the complementary capabilities of partners (Das and Teng, 2000; Gomes-Casseres, 1996). Complementarity refers to the distinctive competencies of both partners (Hill and Hellriegel, 1994). Our study supports this perspective by showing that having the appropriate internal capabilities is a prerequisite for capitalizing on a partner's capabilities. When internal technological capabilities are not sufficiently specialized, the HTNF may fail to profit from knowledge capabilities of upstream and horizontal alliance partners. In contrast, when capabilities are too specialized, accessing manufacturing and marketing capabilities through downstream alliances may depress rather than enhance the firm's NPD efforts.

\subsection{Implications for managerial practice}

HTNFs are often established to exploit opportunities by developing and introducing new products to markets. Given the limitations of their skills and experiences, these firms often join alliances - sometimes even under unfavorable conditions. Our results highlight the importance of HTNFs recognizing the risks associated with strategic alliances. Driven to develop and commercialize new products, reduce costs and shorten the NPD cycle, new firm managers sometimes overlook these risks and join alliances that do not give them a competitive advantage. Partners are often attracted to HTNFs because of their inventiveness in creating products that could change the industry and rules of competition. Our results indicate that HTNFs' managers should consider their own technological capabilities when considering an alliance partner. In particular, the specialization of HTNFs' technological capabilities can significantly influence their ability to acquire or access additional capabilities from external sources. These capabilities have differential effects with different types of alliances. Thus, matching new firms' technological capabilities (especially their specialization) with the types of alliances they join can influence their knowledge and other types of gains.

\subsection{Limitations and future research}

This study's findings should be interpreted with its limitations in mind. For instance, the results draw attention to the importance of the breadth versus depth of the degree of a firm's technological specialization, an issue not explored in this study. Future researchers would benefit from determining whether breadth and depth have different effects on NPD. It is also important to establish if HTNFs can have a variety of technological capabilities and still excel in all these capabilities. This will help improve our appreciation of the importance of the diversity of technological capabilities for the survival, success, growth and the evolution of high technology new firms. Researchers need also to explore how the scope of these firms' technological capabilities 
influences the variety of other capabilities they develop internally or access externally. Consequently, it would be useful to examine the implications of having these technological and other capabilities (e.g., alliance capabilities) for building HTNFs' knowledge base (and hence absorptive capacity).

Our results are also derived from the biotechnology sector, a prominent example of science intense and collaborative industry. Biotechnology firms usually have to cover the gamut of activities that occur between invention and commercialization, necessitating a large number of alliances especially in the downstream portion of their value chain. Given that this increasing number of cooperative relationships is also common in other industries (Arora et al., 2001), future research should validate our findings in other industries.

\section{Conclusion}

New firms in high technology industries have used alliances to gain the knowledge and other resources necessary for successful NPD. Despite their benefits, alliances pose significant risks for HTNFs. This study draws on the capabilities perspective of alliance formation and a survey of 199 biotechnology firms from Germany and the UK to investigate how alliance patterns influence NPD. We find that the specialization of new firms' technological capabilities can help managers use alliances more productively when it comes to NPD. Our results are stable over a variety of different model specifications and when we account for the endogeneity of alliances. The analyses reveal differential effects for upstream, horizontal, and downstream alliances. For those alliances where the acquisition and generation of knowledge is a key goal for HTNFs (i.e., upstream and horizontal), specialized technological capabilities appear to be a prerequisite for developing the absorptive capacity needed to capture and commercially exploit this knowledge. Even if a partner's knowledge is not related to the HTNFs' knowledge domain, its specialized capabilities might be beneficial in using these alliances because they help in gaining a reputation in a particular knowledge domain and as a result better upstream partners. They also protect a firm's knowledge from expropriation by partners in the "co-opetition" scenario of horizontal alliances. When access to capabilities downstream of the value chain is the main driver of alliance formation, a broader set of technological capabilities can increase HTNFs' bargaining power and gains in NPD. The findings help to clarify the role of new firms' technological capabilities in determining the potential benefits and risks associated with strategic alliances especially when it comes to NPD, a source of competitive advantage.

\section{Acknowledgements}

We thank the editor and two anonymous referees for their useful comments, as well as seminar participants at the 2008 Academy of Management Meeting in Anaheim, USA, the 2008 Babson College Entrepreneurship Research Conference at the University of North-Carolina, Chapel Hill, USA, and seminar participants at INNO-tec, Munich, Germany. Haeussler acknowledges financial support from the German Research Foundation (DFG) through SFB/TR15 "Governance and the Efficiency of Economic Systems" and the Munich Center for Health Sciences.

\section{References}

Aghion, P., Tirole, J., 1994. The management of innovation. The Quarterly Journal of Economics 109, 1185-1209.

Ahuja, G., 2000. The duality of collaboration: inducements and opportunities in the formation of interfirm linkages. Strategic Management Journal 21, 317-343. Alvarez, S.A., Barney, J.B., 2001. How entrepreneurial firms can benefit from alliances with large partners. The Academy of Management Executive 15, 139-148. Amit, R., Schoemaker, P.J., 1993. Strategic assets and organizational rent. Strategic Management Journal 14, 33-46.

Angrist, J., 2001. Estimations of limited dependent variable models with dummy endogenous regressors: simple strategies for empirical practice. Journal of Business and Economic Statistics 19 (1), 2-16.

Argyres, N.S., Liebeskind, J.P., 1998. Privatizing the intellectual commons: universities and the commercialization of biotechnology. Journal of Economic Behavior \& Organization 35, 427-545.

Arora, A., Gambardella, A., 1994. Evaluating technological information and utilizing it: scientific knowledge, technological capability, and external linkages in biotechnology. Journal of Economic Behavior \& Organization 24, 91-114.

Arora, A., Fosfuri, A., Gambardella, A., 2001. Markets for technology and their implications for corporate strategy. Industrial and Corporate Change 10 (2), 419-451.

Baum, J.A., Calabrese, T., Silverman, B.S., 2000. Don't go it alone: alliance network composition and startup's performance in Canadian biotechnology. Strategic Management Journal 21, 267-294.

Bengtsson, M., Kock, S., 2000. “Coopetition” in business networks - to cooperate and compete simultaneously. Industrial Marketing Management 29, 411-427.

Bower, D., 1992. Company and Campus Partnership. Routledge, New York NY.

Brandenburger, A.M., Nalebuff, B.J., 1996. Co-opetition. Doubleday, New York.

Buergel, O., Fier, A., Licht, G., Murray, G., 2002. The effect of internationalisation on the rate of growth of high-tech start-ups: evidence for the UK and Germany. In: Schatzl, L., Revilla Diez, J. (Eds.), Technological Change and Regional Development in Europe. Physica, Heidelberg, pp. 74-89.

Burgers, W.P., Hill, C.W., Kim, W.C., 1993. A theory of global strategic alliances: the case of the global auto industry. Strategic Management Journal $14,419-432$. Cameron, C., Trivedi, P., 1998. Regression Analysis of Count Data. Cambridge University Press, New York.

Carayannis, E.G., Alexander, J., 1999. Winning by co-opeting in strategic government-university-industry R\&D partnerships: the power of complex, dynamic knowledge networks. Journal of Technology Transfer 24 (2-3), 197-210.

Cassiman, B., Veugelers, R., 2002. R\&D cooperation and spillovers: some empirical evidence from Belgium. The American Economic Review 92 (4), $1169-1184$.

Cohen, W.M., Levinthal, D.A., 1990. Absorptive capacity: a new perspective on learning and innovation. Administrative Science Quarterly 35, $128-152$.

Cullen, W.C., Dibner, M.D., 1993. Strategic alliances in biotechnology: imperatives for the 1990s. Biotechnology Review 1, $110-119$.

Das, T.K., Teng, B.-S., 2000. A resource-based theory of strategic alliances. Journal of Management 26, 31-61.

Dasgupta, P., David, P.A., 1994. Toward a new economics of science. Research Policy 23, 487-521.

D'Aveni, R.A., 1994. Hypercompetition: Managing the Dynamics of Strategic Maneuvering. Free Press, New York NY.

D'Aveni, R.A., 1995. Coping with hypercompetition: utilizing the new 7S's framework. Academy of Management Executive 9, 45-57.

De Carolis, D., Deeds, D., 1999. The impact of stocks and flows of organizational knowledge on firm performance: an empirical evaluation of the biotechnology industry. Strategic Management Journal 20, 953-968. 
Deeds, D.L., Hill, C.W.L., 1996. Strategic alliances and the rate of new product development: an empirical study of entrepreneurial biotechnology firms. Journal of Business Venturing 11, 41-55.

Deeds, D.L., Hill, C.W.L., 1998. An examination of opportunistic action within research alliances: evidence from the biotechnology industry. Journal of Business Venturing 14, 141-163.

Deeds, D., Hill, C., 1999. An examination of opportunistic action within research alliances: Evidence from the biotechnology industry. Journal of Business Venturing $14,141-163$.

Deeds, D.L., DeCarolis, D.M., Coombs, J.E., 1999. Dynamic capabilities and new product development in high technology ventures: an empirical analysis of new biotechnology firms. Journal of Business Venturing 15, 211-229.

DiMasi, J.A., Hansen, R.W., Grabowski, H.G., 2003. The price of innovation: new estimates of drug development costs. Journal of Health Economics 22, 151-185.

Eisenhardt, K.M., Schoonhoven, C.B., 1996. Resource-based view of strategic alliance formation: strategic and social effects in entrepreneurial firms. Organization Science 7 (2), 136-150.

Emden, Z., Calantone, R.J., Droge, C., 2006. Collaborating for new product development: selecting the partner with maximum potential to create value. The Journal of Product Innovation Management 23, 330-341.

Ernst \& Young, 2008. Beyond Borders - Global Biotechnology Report 2008. EYGM, London.

Evans, A.G., Varaiya, N.P., 2003. Assessment of a biotech market opportunity. Entrepreneurship Theory and Practice 28, 87-105.

Gans, J.S., Stern, S., 2003. The product market and the market for 'ideas': commercialization strategies for technology entrepreneurs. Research Policy 32, $333-350$.

Geisler, E., 1995. Industry-university technology cooperation: a theory of inter-organizational relationships. Technology Analysis \& Strategic Management 7, 217-229.

Geisler, E., Furino, A., Kiresuk, T.J., 1990. Factors in the success or failure of industry-university cooperative research centers. Interfaces 20, $99-110$.

George, G., Zahra, S.A., Wheatley, K.K., Khan, R., 2001. The effects of alliance portfolio characteristics and absorptive capacity on performance: a study of biotechnology firms. Journal of High Technology Management Research 12, 205-226.

George, G., Zahra, S.A., Wood, D.R., 2002. The effect of business-university alliances on innovative output and financial performance: a study of publicly traded biotechnology companies. Journal of Business Venturing 17, 577-609.

Gnyawali, D.R., Madhavan, R., 2001. Cooperative networks and competitive dynamics: a structural embeddedness perspective. Academy of Management Review 26 (3), 431-445.

Gnyawali, D.R., He, J., Madhavan, R., 2006. Impact of co-opetition on firm competitive behavior: an empirical examination. Journal of Management 32 (4), 507-530.

Gomes-Casseres, B., 1996. The Alliance Revolution: The New Shape of Business Rivalry. Harvard University Press, Cambridge MA.

Grabowski, H., Vernon, J., 1990. A new look at the returns and risks to pharmaceutical R\&D. Management Science 36 (7), $167-185$.

Greene, W.H., 2003. Econometrics Analysis, Fifth Edition. Upper Saddle River, NJ, Prentice Hall.

Grindley, P., Mowery, D.C., 1994. SEMATECH and collaborative research: lessons in the design of high-technology consortia. Journal of Policy Analysis and Management 13, 723-758.

Gulati, R., 1998. Alliances and networks. Strategic Management Journal 19, 293-317.

Gulati, R., Higgins, M., 2003. When do ties matter? A contingent model of the implications of interorganizational partnerships for IPO and post-IPO success. Strategic Management Journal 24 (2), 127-144.

Haagen, F., Haeussler, C., Harhoff, D., Murray, G., Rudolph, B., 2007. Finding the Path to Success - The Structure and Strategies of British and German Biotechnology Companies. LMU, Munich.

Haeussler, C., 2010a. Information-sharing in academia and the industry: a comparative study. Research Policy. doi:10.1016/j.respol.2010.08.007.

Haeussler, C., 2010b. The determinants of commercialization strategy - idiosyncrasies in British and German biotechnology. Entrepreneurship Theory \& Practice 35(3). doi:10.1111/j.1540-6520.2010.00385.x.

Hagedoorn, J., 1993. Understanding the rationale of strategic technology partnering: interorganizational modes of cooperation and sectoral differences. Strategic Management Journal 14, 371-385.

Hamel, G., 1991. Competition for competence and interpartner learning within international strategic alliances. Strategic Management Journal 12, 83-104 Special Issue Summer.

Hamel, G., Doz, Y.L., Prahalad, C.K., 1989. Collaborate with your competitors-and win. Harvard Business Review 67, 133-139 Jan-Feb.

Henderson, R., 1993. Underinvestment and incompetence as responses to radical innovation: evidence from the photolithographic alignment equipment industry. The Rand Journal of Economics 24, 248-270.

Hicks, D., 1995. Published papers, tacit competencies and corporate management of the public/private character of knowledge. Industrial and Corporate Change 4 (2), 401-424.

Higgins, M.C., Gulati, R., 2006. Stacking the deck: the effects of top management backgrounds on investor decisions. Strategic Management Journal 27, 1-25.

Hill, R.C.L., Hellriegel, D., 1994. Critical contingencies in joint venture management: some lessons from managers. Organization Science 5, 594-607.

Hoang, H., Rothaermel, F.T., 2005. The effect of general and partner-specific alliance experience on joint R\&D project performance. Academy of Management Journal 48, 332-345.

Hoetker, G., 2005. How much you know versus how well I know you: selecting a supplier for a technically innovative component. Strategic Management Journal 26, 75-96.

Jain, B., Kini, O., 1995. Venture capitalist participation and the post-issue operating performance of IPO firms. Managerial and Decision Economics 16, 593-606.

Khanna, T., Gulati, R., Nohria, N., 1998. The dynamics of learning alliances: competition, cooperation and relative scope. Strategic Management Journal 19, $193-210$.

Kogut, B., 1988. Joint ventures: theoretical and empirical perspectives. Strategic Management Journal 9, 319-332.

Kogut, B., Zander, U., 1992. Knowledge of the firm, combinative capabilities, and the replication of technology. Organization Science 3, 383-397.

Lado, A.A., Boyd, N.G., Hanlon, S.C., 1997. Competition, cooperation, and the search for economic rents: a syncretic model. Academy of Management Review 22 (1), $110-141$.

Lane, P.J., Lubatkin, M., 1998. Relative absorptive capacity and interorganizational learning. Strategic Management Journal $19,461-477$.

Leiblein, M.J., Miller, D.J., 2003. An empirical examination of transaction and firm-level influences on the vertical boundaries of the firm. Strategic Management Journal 24, 839-859.

Leonard-Barton, D., 1995. Wellsprings of Knowledge, Building and Sustaining the Sources of Innovation. Harvard Business School Press, Boston.

Lerner, J., Merges, R.P., 1998. The control of technology alliances: an empirical analysis of the biotechnology industry. The Journal of Industrial Economics 46, $125-156$.

Lerner, J., Shane, H., Tsai, A., 2003. Do equity financing cycles matter? Evidence from biotechnology alliances. Journal of Financial Economics 67, $411-446$.

Lewis, G., 1990. Partnerships for Profit: Structuring and Managing Strategic Alliances. The Free Press, New York NY.

Madhok, A., Tallman, S., 1998. Resources, transactions and rents: managing value through interfirm collaborative relationships. Organization Science 9 (3), 326-339.

March, J.G., 1991. Exploration and exploitation in organizational learning. Organization Science 2, 71-87.

Martin, X., Salomon, R., 2003. Tacitness, learning, and international expansion: a study of foreign direct investment in a knowledge-intensive industry. Organization Science 14, 197-311.

Mayer, K.J., Nickerson, J.A., 2005. Antecedents and performance implications of contracting for knowledge workers: evidence from information technology services. Organization Science 16, 225-242.

Mayer, K.J., Salomon, R., 2006. Capabilities, contractual hazards, and governance: integrating resource-based and transaction cost perspectives. Academy of Management Journal 49, 942-959.

McKelvey, M., 1996. Evolutionary Innovations: The Business of Biotechnology. Oxford University Press, Oxford, UK.

Mowery, D.C., Oxley, J.E., Silverman, B.S., 1996. Strategic alliances and interfirm knowledge transfer. Strategic Management Journal 17, 77-91. 
Mullahy, J., 1997. Instrumental-variable estimation of count data models: applications to models of cigarette smoking behavior. The Review of Economics and Statistics 79 (4), 586-593.

Nelson, R.R., Winter, S., 1982. An Evolutionary Theory of Economic Change. The Belknap Press of Harvard University Press, Cambridge MA.

OECD, 2005. Compendium of Patent Statistics. OECD, Paris.

Oliver, A.L., Liebeskind, J.P., 1998. Three levels of networking for sourcing intellectual capital in biotechnology: implications for studying interorganizational networks. International Studies of Management \& Organization 27, 76-103.

Owen-Smith, J., Powell, W.W., 2004. Knowledge networks as channels and conduits: the effects of spillovers in the Boston biotechnology community. Organization Science 15 (1), 5-21.

Pakes, A., 1985. On patents, R\&D, and the stock market rate of return. Journal of Political Economy 93 (2), 390-409.

Park, S.H., Russo, M.V., 1996. When competition eclipses cooperation: an event history analysis of joint venture failure. Management Science 42, 875-890.

Patzelt, H., Shepherd, D.A., Deeds, D., Bradley, S.W., 2008. Financial slack and venture managers' decisions to seek a new alliance. Journal of Business Venturing 23, 465-481.

Perry, M.L., Sengupta, S., Krapfel, R., 2004. Effectiveness of horizontal strategic alliances in technologically uncertain environments: are trust and commitment enough? Journal of Business Research 57, 951-956.

Pisano, G.P., 1990. The R\&D boundaries of the firm: an empirical analysis. Administrative Science Quarterly 35, 153-176.

Powell, W.W., Koput, K.W., Smith-Doerr, L., 1996. Interorganizational collaboration and the locus of innovation: networks of learning in biotechnology. Administrative Science Quarterly 41, 116-145.

Powell, W.W., White, D.R., Koput, K.W., Owen-Smith, J., 2005. Network dynamics and field evolution: the growth of interorganizational collaboration in the life sciences. The American Journal of Sociology 110, 1132-1205.

Rothaermel, F.T., 2001. Incumbent's advantage through exploiting complementary assets via interfirm collaboration. Strategic Management Journal 22, 687-699.

Rothaermel, F.T., Deeds, D.L., 2004. Exploration and exploitation alliances in biotechnology: a system of new product development. Strategic Management Journal $25,201-221$

Rothaermel, F.T., Deeds, D.L., 2006. Alliance type, alliance experience and alliance management capability in high-technology ventures. Journal of Business Venturing 21, 429-460.

Sapienza, H.J., 1992. When do venture capitalists add value? Journal of Business Venturing 7, 9-28.

Schrader, S., 1991. Informal technology transfer between firms: cooperation through information trading. Research Policy 20, $153-170$.

Shan, W., Walker, G., Kogut, B., 1994. Interfirm cooperation and startup innovation in the biotechnology industry. Strategic Management Journal 15, 387-394.

Smith, B.J., Barclay, D.W., 1997. The effects of organizational differences and trust on the effectiveness of selling partner relationships. Journal of Marketing 61, $3-21$.

Sorensen, J.B., Stuart, T.E., 2000. Aging, obolescence, and organizational innovation. Administrative Science Quarterly 45, 81-112.

Stuart, T.E., Hoang, H., Hybels, R.C., 1999. Interorganizational endorsements and the performance of entrepreneurial ventures. Administrative Science Quarterly 44, 315-349.

Tapon, F., 1989. A transaction cost analysis of innovations in the organization of pharmaceutical R\&D. Journal of Economic Behavior and Organization 12, 197-213.

Teece, D.J., 1986. Profiting from technological innovation: implication for integration, collaboration, licensing and public policy. Research Policy $15,285-305$.

Teece, D.J., Pisano, G., Shuen, A., 1997. Dynamic capabilities and strategic management. Strategic Management Journal 18, $509-533$.

von Hippel, E., 1987. Cooperation between rivals: informal know-how trading. Research Policy 16, 291-302.

Zahra, S.A., 1996. Technology strategy and new venture performance: a study of corporate-sponsored and independent biotechnology ventures. Journal of Business Venturing 11, 289-321.

Zahra, S.A., George, G., 2002. Absorptive capacity: a review, reconceptualization, and extension. Academy of Management Review 27, $185-203$.

Zhang, J., Baden-Fuller, C., Mangematin, V., 2007. Technological knowledge base, R\&D organization structure and alliance formation: evidence from the biopharmaceutical industry. Research Policy 36, 515-528.

Zucker, L.G., Darby, M.R., Armstrong, J.S., 2002. Commercializing knowledge: university science, knowledge capture, and firm performance in biotechnology. Management Science 48, 138-153. 